\title{
脂肪細胞分化初期の分子機構及び新規分化制御因子の有する多彩な生理機能に関する研究
}

\author{
今川正良
}

\section{Molecular Mechanisms of Early-stage Adipocyte Differentiation and Multi-functional Roles of Newly Isolated Adipogenic Factors}

\author{
Masayoshi Imagawa \\ Department of Molecular Biology, Graduate School of Pharmaceutical Sciences, \\ Nagoya City University; 3-1 Tanabe-dori, Mizuho-ku, Nagoya 467-8603, Japan.
}

(Received September 16, 2015)

\begin{abstract}
Obesity is a major risk factor for diabetes, hypertension, hyperlipidemia, and arteriosclerosis. Although the middle and late stages of adipocyte differentiation are well characterized, the earliest step in the differentiation process has remained largely unknown. We isolated 102 genes expressed at the beginning of the differentiation of a mouse preadipocyte cell line, 3T3-L1 cells. Because approximately half of these genes were unknown, we named them factor for adipocyte differentiation $(\mathrm{fad})$ genes. I first show how these genes regulate the early stage of adipocyte differentiation. We next generated fad104-deficient mice, and demonstrated that fad104-deficient mice died due to cyanosis-associated lung dysplasia with atelectasis. We also found that fad104 positively regulated adipocyte differentiation and negatively regulated osteoblast differentiation. We then demonstrated that fad24-knockdown inhibited mitotic clonal expansion (MCE) and that FAD24 contributed to the regulation of DNA replication by recruiting histone acetyltransferase binding to ORC1 (HBO1) to DNA replication origins. In vitro culture experiments revealed that fad24-null embryos developed normally to the morula stage, but acquired growth defects in subsequent stages. These results strongly suggest that fad 24 is essential for pre-implantation in embryonic development, particularly for progression to the blastocyst stage. These findings together indicate that both $\mathrm{fad} 104$ and $\mathrm{fad} 24$ contribute not only to adipogenesis but also to other physiological events. The multi-functional roles of these genes are discussed.
\end{abstract}

Key words — adipocyte differentiation; obesity; DNA replication; lung maturation; osteoblast differentiation; embryonic development

\section{1. はじめに}

肥満は, 糖尿病, 脂質代謝異常症, 高血圧症など の主要なリスクファクターであり, ${ }^{1-4)}$ 肥満の分子 機構解明は，健康科学を考える上で，わが国だけで なく世界的にも最重要課題の 1 つである. ${ }^{5-7)}$ 肥満 形成には，脂肪細胞の肥大化が大きく寄与している ことが古くから知られていた。実際，肥大化した成 熟脂肪細胞では，過剩なエネルギーを蓄積した脂肪 滴が形成され，種々の生理活性物質の分泌量が変わ るという質的な変化が起こる，一方，脂肪細胞の肥 大化に加え, 前駆脂肪細胞から脂肪細胞への分化に よる脂肪細胞の数の増加, すなわち量的な変化も肥

名古屋市立大学大学院薬学研究科分子生物薬学分野 ( ( $467-8603$ 名古屋市瑞穂区田辺通 3-1)

e-mail: imagawa@phar.nagoya-cu.ac.jp

本総説は, 平成 27 年度日本薬学会学術貢献賞の受賞を 記念して記述したものである。
満形成の大きな要因であることが明らかとなり，脂 肪細胞分化の解析を通じた肥満の分子機構が急速に 明らかにされてきた. ${ }^{8)}$

脂肪細胞は，筋や軟骨などの前駆細胞と同じ起源 を持つ中胚葉系幹細胞より発生し, 前駆脂肪細胞を 経て成熟脂肪細胞へと分化する. 脂肪細胞分化の研 究には, マウス前駆脂肪細胞株 3T3-L1 細胞が沉用 されている.この細胞は，コンフレント（培養血の 中で細胞がいつぱいに増殖した状態）に達した後, インスリンなどの分化誘導剤を添加すると mitotic clonal expansion（MCE）（詳細は後述する）という 1-2 回の細胞分裂を経て成熟脂肪細胞へと分化す る. 誘導 6 日目以降には脂肪滴が観察されるように なり，10 日程度で成熟脂肪細胞となる（Fig. 1). 細胞レベル及び分子レベルでの多くの研究により, peroxisome proliferator-activated receptor $\gamma$ (PPAR $\gamma)$, CCAAT/enhancer-binding protein $\alpha$ (C) 


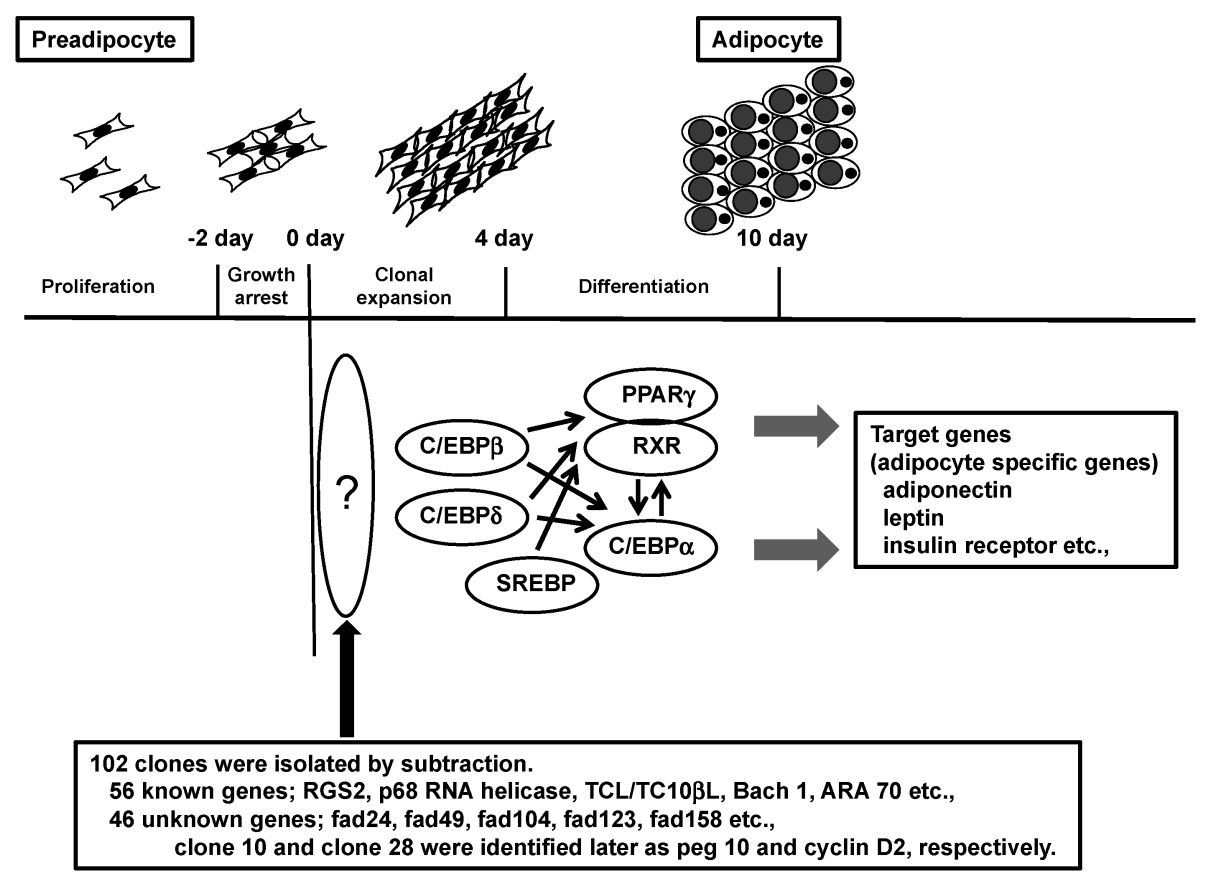

Fig. 1. Signaling Network in Adipocyte Differentiation

$\mathrm{EBP} \alpha), \mathrm{C} / \mathrm{EBP} \beta, \mathrm{C} / \mathrm{EBP} \delta$ 及び sterol regulatory element-binding protein 1 (SREBP1) が脂肪細胞分 化を制御する転写因子として重要な役割を果たして いることが明らかにされた. ${ }^{9,10)}$ 現在では, 脂肪細 胞はPPAR $\gamma$ を介する唯一の経路を通じて分化する ことが明らかとなっている。一方， $\mathrm{C} / \mathrm{EBP} \alpha$ は脂 肪細胞のインスリン感受性を制御すると考えられて いる. ${ }^{11)}$

なお, 1990 年代は, 脂肪細胞分化の成熟過程を 含め日単位での検討がなされていた。したがって, 上記の因子群はすべて脂肪細胞初期に発現すると記 された当時の論文も多い。しかし実際には, $\operatorname{PPAR} \gamma, \mathrm{C} / \mathrm{EBP} \alpha, \mathrm{SREBP} 1$ の発現が上昇するのは 脂肪細胞分化誘導後 2-4 日目以降であった. また,

$\mathrm{C} / \mathrm{EBP} \beta$ と $\mathrm{C} / \mathrm{EBP} \delta$ は $\mathrm{C} / \mathrm{EBP} \alpha$ よりも早く発現す るものの, それ以前，すなわち脂肪細胞分化の最も 初期における遺伝子群の変化については不明な点が 多く残されていた。1992 年に Sadowski らは, 3T3-L1 細胞を用いて，その分化初期に発現が変動 するタンパク質が多数存在することを二次元電気泳 動で明らかにした。 そのうち，100 種類以上のタン パク質が分化誘導 5 時間以内に発現が変動した. ${ }^{12)}$ しかし当時は詳細な解析はなされていなかった。 そ こでわれわれは, 脂肪細胞分化初期の分子メカニズ ムを解明するために, マウス前駆脂肪細胞株 3T3-

L1 細胞の分化誘導 3 時間後に発現が増加する遺伝 子を多数単離した。本総説では, これら単離した遺 伝子群の中で特に重要と思われる遺伝子の脂肪細胞 分化における役割について概説する。新規遺伝子に ついては, 脂肪細胞分化以外についても多彩な機能 を有することを明らかにしたので合わせて紹介する.

\section{2. 脂肪細胞分化初期に発現が上昇する遺伝子群 の単離}

前述のように, マウス前駆脂肪細胞株である 3T3-L1 細胞は，分化誘導剂を添加すると 1 週間ほ ぞで脂肪滴を含む脂肪細胞へと分化する.われわれ は分化誘導前と分化誘導 3 時間後の細胞を用いて PCR-サブトラクション法により誘導 3 時間後に発 現が上昇する遺伝子群を単離した（Fig. 1)。その 結果, 単離した計 310 クローンのうち 228 クローン が independent クローンであったため, これら全ク ローンの ${ }^{32} \mathrm{P}$ 標識プローブを用いてノザンブロット

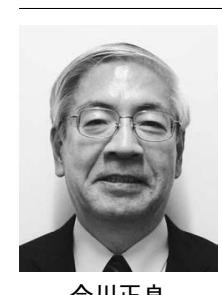

今川正良
1975 年千葉大学薬学部卒業. 1980 年大 阪大学大学院薬学研究科博士課程修 了. 宮崎医科大学助手, 大阪大学薬学 部助手, 東京大学医学部助手, 大阪大 学薬学部助教授を経て, 2000 年名古屋 市立大学薬学部教授. この間, 1985 年 より 1987 年まで, カリフォルニア大学 などに留学. 2006 年より 2014 年まで 名古屋市立大学理事・副学長. 
解析を行い，分化誘導 3 時間後に発現が上昇する遺 伝子群として最終的に 102 クローンを単離し た. ${ }^{13-16)}$ 単離した遺伝子リストについては，文 献 15,16 を参照されたい.

ここで余談を 1 つ記す，mRNAの定量は現在で はリアルタイム PCR が主であり，ノザンブロット 解析を知らない学生も増えている。 ノザンブロット 解析では通常 ${ }^{32} \mathrm{P}$ 標識プローブを使用するが，その 作製の際には未反応の $\left[\alpha^{-32} \mathrm{P}\right] \mathrm{dCTP}$ をスピンカラ ムなどで取り除く必要がある。プローブの数の多さ に見かねて市販のスピンカラムを購入するように学 生に勧めたところ，それほど大変な作業ではない， 市販品は高いといいながら， $1 \mathrm{~mL}$ のシリンジにグ ラスウール，ついで Sephadex-G50 を詰め，32 種類 の標識プローブを一気にかつ淡々と低速遠心機（8 $\times 4$ の 32 本架け）にかける姿をみて喂然としたこ とを今でも覚えている，原理をしつかり理解して実 験しているのでトラブルも少なく，問題が生じたと きの対応も素早い。最近の分子生物学実験ではキッ トが溢れているが，原理を理解せず使用するためト ラブルにも対処できない。キットを使う前に一度は 手製で行うことを研究室で推奨しているが，今後益 々このような問題が増えると思われる。

話を元に戻す．次に単離した 102 クローンの中の うち, より重要と思われる遺伝子の選別を行った。 当時はゲノム配列情報， cDNA 配列情報が不十分 であったことに加え，PCR-サブトラクション法で は数百塩基の DNA 断片しか得られないことから, 102 クローンのうち 46 クローンは未知遺伝子で あつた。そこで，未知遺伝子については，全長 cDNA 取得を目指した。残りの既知遺伝子 56 ク ローンについては，1）マウス遺伝子とヒト遺伝子 の比較，2）発現変化の顕著な遺伝子，3）細胞の増 殖時と非増殖時の発現変化の違いを検討した。 3 ) の検討では，前述の 3T3-L1 マウス前駆脂肪細胞株 と同じ線維芽細胞で，通常は脂肪細胞に分化しない NIH-3T3 細胞も対照として用いた。3T3-L1 細胞を 脂肪細胞に分化させるには，前述のように一旦細胞 をコンフレントにして増殖を停止させることが必須 である，そこでこれら 2 種類の細胞の増殖時，非増 殖時に分化誘導剂を添加し，発現変化を観察した。 3T3-L1 細胞の非増殖時のみ顕著な発現上昇を示し た遺伝子をより重要な遺伝子として選択した。 ${ }^{16)}$ そ
の後，発現抑制系及び強制発現系による脂肪細胞へ の分化の影響を検討することにより，重要な遺伝子 をさらに絞り込んだ.

これらの検討により, regulator of G-protein signaling family 2 (RGS2), ${ }^{17)}$ p68 RNA helicase, ${ }^{18)}$ 低 分子量 GTP タンパク質 Rho ファミリーに属する TC-10-like/TC10 $\beta$ Long (TCL/TC10 $\beta \mathrm{L}),{ }^{19)} \mathrm{Maf}$ ファミリーとヘテロダイマーを形成し転写因子とし て働< BTB and CNC homology 1 (Bach1), 15) $\operatorname{PPAR} \gamma$ のコアクチベーターとして機能する androgen receptor associated protein 70 (ARA70) ${ }^{15)}$ など が，脂肪細胞分化初期に一過性に発現上昇するとと もに，脂肪細胞分化に重要な役割を果たしているこ とを明らかにした。また，未知遺伝子の全長 cDNA クローニングの結果，クローン 10 が Peg 10, 20) クローン 28 が cyclin D221) として同定さ れた。一方，遺伝子の情報がなかったクローンにつ いては, factor for adipocyte differentiation (fad) と名付けクローン番号で表した。その結果, fad158, ${ }^{22)}$ fad104, ${ }^{23)}$ fad24, ${ }^{24)}$ fad123 (SLS39A14 と同一), ${ }^{25)} \mathrm{fad} 49^{26)}$ が新規遺伝子として同定され, Peg10 及び cyclin D2 とともにこれらの遺伝子も脂 肪細胞分化初期に深く係わっていることを報告した (Fig. 1).

なお，fad123 については余談がある。fad123 は 全長クローニングの結果，亜鉛トランスポーターと して知られる Zrt/Irt-like protein（ZIP）トランス ポーターに属する LIV-1 subfamily of ZIP transporters）（LZT）サブファミリーの1つである SLC39A14 と同一であることがわかった。この SLC39A14 は他の亜鉛トランスポーターと基本骨格 は共通であるものの，亜鉛結合に必要なモチーフの 一アミノ酸に変異があることから，亜鉛取り込み能

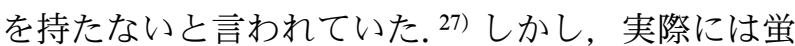
光標識法による亜鉛吸着能を利用した間接的な検討 しかされていなかったことから，われわれは ${ }^{65} \mathrm{ZnCl}_{2}$ を用いた直接的な方法により，SLC39A14 が覀鉛トランスポーターとして機能することを報告 した. ${ }^{25)}$ しかしわれわれが専門外であることも一因 かもしれないが論文は簡単には受理されなかった。 四苦八苦してやっと掲載が決定した頃，亜鉛トラン スポーター能を持たないと言っていたグループが亜 鉛トランスポーター能をわれわれより先に報告し 


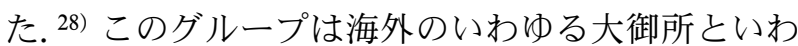
れるグループであり，論文の received の日付を調べ たところ，われわれが最初に投稿したときよりもか なり遅い日付であった．確証のない話なのでこれ以 上は述べないが，その後 SLC39A14 は，亜鉛トラ ンスポーターとしての機能が広く認められることに なった. ${ }^{29)}$ わざわざ ${ }^{65} \mathrm{ZnCl}_{2}$ を用いて実験を行った 甲斐があり，多少は亜鉛トランスポーター研究に貢 献できたものと思っている.

\section{3. 単離した遺伝子群の脂肪細胞分化初期におけ}

\section{る機能}

前駆脂肪細胞が成熟脂肪細胞に分化する際, MCE という過程が必須と言われている (Fig. 1)。 ${ }^{30)}$ 既に述べたように，脂肪細胞の分化研究によく使用 されるマウス前駆脂肪細胞株 3T3-L1 細胞を分化さ せるには，まず細胞をコンフレントにしてから分化 誘導剂を添加する．すると $\mathrm{G} 0$ 期の細胞が $\mathrm{G} 1$ 期に 入り，1-2 回ほど細胞分裂を起こしその後分化に向 かうと言われている. ${ }^{31)}$ 脂肪細胞分化における MCE の必要性については異論もあったが，現時点 ではクロマチンの再構成を経て終末分化に向かうの に必須と考えられている。讘 その際， C/EBP $\beta$ が最 も重要な働きをしていることが報告された. ${ }^{31)} \mathrm{C} /$ $\mathrm{EBP} \delta$ は $\mathrm{C} / \mathrm{EBP} \beta$ とほぼ同時期に発現が上昇する ことから，C/EBP $\delta$ が MCE に与える影響について 検討したところ，C/EBP $\delta$ も MCE に必須であるこ とがわかった. ${ }^{33)}$ その際， C/EBP $\delta$ ノックダウンに より，fad49 の発現が抑制されることも明らかに なった。次に fad49 をノックダウンすると，C/ $\mathrm{EBP} \beta$ 並びに $\mathrm{C} / \mathrm{EBP} \delta$ の発現を抑制し $\mathrm{MCE}$ も抑制 した。さらに次のステージに発現する $\mathrm{C} / \mathrm{EBP} \alpha$, $\operatorname{PPAR} \gamma, \mathrm{SREBP}-1$ などの転写因子の発現もすべて 抑制された. ${ }^{26)}$ したがって，C/EBP $\delta$ と fad49 は脂 肪細胞分化初期にお互いに発現を制御しながら MCE に係わっているものと思われた.

このように MCE に関与する遺伝子が得られたこ ともあり，単離した遺伝子群のうちどの遺伝子が MCE に係わっているか次に検討した。 上記 2 . で単 離した遺伝子群のうち，TCL/TC10 $\beta \mathrm{L}, \mathrm{RGS} 2$, fad104 及び fad158 の 4 つの遺伝子をそれぞれノッ クダウンし MCE に対する影響を検討した. ${ }^{34)}$ その 結果，TCL/TC10 $\beta \mathrm{L}$ は MCE に深く関与し， RGS2 と fad104 はわずかな影響を有し，fad158 は全く影 響を与えないことが明らかとなつた。fad158 はほ かの 3 つの遺伝子よりもわずかに遅れて発現するこ とが影響しなかった要因かもしれない。TCL/ TC10 $\beta \mathrm{L}$ は，Rho ファミリーに属する低分子 G 夕 ンパク質であるが， TCL/TC10 $\beta \mathrm{L}$ により制御され る遺伝子群の探索を並行して検討していた。 その中 にアクチンフィラメント形成に係わる遺伝子の gelsolin が含まれていた. ${ }^{19)}$ そこで MCEへの影響を調 べたところ，gelsolin を発現抑制することにより MCE が阻害された。このとき， $\mathrm{C} / \mathrm{EBP} \alpha, \operatorname{PPAR} \gamma$ の発現も抑制されたが， $\mathrm{C} / \mathrm{EBP} \beta$ と $\mathrm{C} / \mathrm{EBP} \delta$ の発 現は影響を受けなかった. ${ }^{35)} こ れ ら の$ 結果は, gelsolin が $\mathrm{C} / \mathrm{EBP} \beta$ と $\mathrm{C} / \mathrm{EBP} \delta$ より遅れて機能してい ることを示している。 また共同研究の過程で得られ た potassium channel, subfamily $\mathrm{K}$, member 10 (KCNK10) も MCE を正に制御することを見い出し た. ${ }^{36)}$

上記の因子群はすべて脂肪細胞分化初期において 分化を正に制御しているが，それらの一部は $\mathrm{MCE}$ への関与を介して分化を制御していることが明らか となつた. MCE については, fad 24 の関与を後述 するが，複数の因子が複雑に制御しあっており，全 容解明には更なる検討が必要と思われる.

\section{4. ノックアウトマウスによる解析}

当時（2002 年）は, cDNA 情報もゲノム情報も 十分ではなく, 前述した $\mathrm{fad}$ はもちろんのこと, 脂 肪細胞分化に関与することを明らかにした既知遺伝 子でさえ，生体内における機能は不明な点が多く残 されていた。 そこで次に, 大阪大学微生物病研究所 附属遺伝情報実験センターの岡部 勝研究室との共 同研究によりノックアウトマウスの作製を試みた.

MCE については，その重要性が認知される前に作 製を開始したため，ノックアウトマウスを作製する 遺伝子の選択条件にはいれず，下記の観点から 4 つ の遺伝子を選んだ。1）fad 24 ; 転写因子 C/EBP ファミリーが有するロイシンジッパーの構造に類似 した配列を有することから，転写因子として機能し ていることを期待した。2） fad104；非増殖時の 3T3-L1 での夕特異的に発現が上昇すること，白色 脂肪組織において発現が顕著に高いこと，さらに フィブロネクチン type III ドメインを有することな どから面白い機能が見つかることを期待した．3） fad158； $\mathrm{N}$ 末端に膜貫通領域， $\mathrm{C}$ 末端にロイシン 
FAD24

bZip-like NOC

807 aa

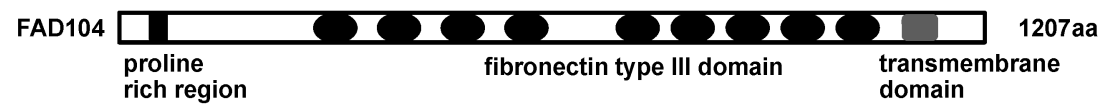

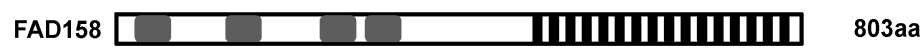

transmembrane domain leucine-rich repeat region (LRR)

Fig. 2. Schematic Structures of Mouse FAD24, FAD104 and FAD158

リッチモチーフを有すること, 単離した遺伝子群の 中では相対的には遅い 6 時間後に発現がピークにな ることから，他の因子とは異なる機能を期待した。

4） TCL/TC10 $\beta \mathrm{L}$; 既知遺伝子ではあるが，非増殖 時の 3T3-L1 でのみ特異的に発現が上昇すること,

Rho GTPase としての存在が明らかにされたばかり で機能が不明であったことから新しい知見が得られ ることを期待した。これら 4 つの遺伝子について, 脂肪細胞分化以外の機能も想定し全身性ノックアウ トマウスを作製した。 fad24, fad104,fad158 につい ては, その構造の概略を Fig. 2 に示した.

TCL/TC10 $\beta \mathrm{L}$ と fad158については比較的スムー スにヘテロ及びホモノックアウトマウスが得られ た. 続いて fad158 ノックアウトマウスの肥満形成 に与える影響を検討したところ，高脂肪食を与えた 際に弱いながらもインスリン抵抗性減弱作用が観察 されたが，それ以外では明確な差は得られなかっ た. ${ }^{37)}$ fad158は leucine-rich repeat containing 8c (LRRC8c) と同一であることが現在では知られてい る. LRRC8 ファミリーは少なくとも 5 種類で構成 されているため, ファミリー全体の解析が今後の課 題である. ${ }^{38)}$ また, TCL/TC10 $\beta \mathrm{L}$ ホモノックアウ トマウスについても高脂肪食摂取実験や糖代謝能の 解析を行つたが明確な差は得られなかつた (未発表).

Rho GTPase は 8 つのサブファミリー, 計 21 種類 よりなることが現在では知られているが，TCL/ $\mathrm{TC} 10 \beta \mathrm{L}$ は, TC10 とともに Cdc42 と同じサブファ ミリーに属している. 脂肪細胞分化過程における $\mathrm{TCL} / \mathrm{TC} 10 \beta \mathrm{L}$ の発現パターンは TC10 及び Cdc42 とは全く異なることを報告しているものの, ${ }^{19)} よ り$ 詳細な解析が必要である。なお，われわれが TCL/ $\mathrm{TC} 10 \beta \mathrm{L}$ を単離した当初は Rho（TC10）と呼んで
いた. ${ }^{13)}$ 単離したマウスクローンの DNA 配列がヒ トRho（TC10）と 97\%の類似性があったため, Rho（TC10）のマウスオルソログと判断したが, その後新たに同定された TCL $/ \mathrm{TC} 10 \beta \mathrm{L}$ と同一であ ることが判明した. ${ }^{19)}$ 現在では， TCL/TC10 $\beta \mathrm{L}$ は Rho J, TC10 は Rho Q と呼ぶことが提唱されてい る. ${ }^{39)}$

ここで再び余談である. 1980 年代後半から 1990 年代前半は, cDNA としてデータベースに登録さ れている遺伝子はそれほど多くなく, 種々の新規遺 伝子が次々と報告・登録されていた，結果として同 一遺伝子であることが後で判明することも多かった が，研究者の思い入れもあり独自の名称でそれぞれ 論文発表していた。冒頭で登場した C/EBP という 遺伝子名の由来は次の通りである. ${ }^{40)}$ 最初はラット の核抽出液から見い出された DNA 結合タンパク質 であり，その結合配列は一見無関係な CCAAT ボックスとエンハンサー配列であったことから CCAAT/ enhancer-binding protein (C/EBP) と呼 ばれた。 その後ファミリーを形成していることがわ かったため, $\mathrm{C} / \mathrm{EBP} \alpha$ と命名し直した。 $\mathrm{C} / \mathrm{EBP} \beta$ は命名されるまで, nuclear factor-IL6 (NF-IL6), liver activator protein (LAP), IL6-induced DNA binding protein (IL6-DBP), alpha-1 acid glycoprotein/enhancer-binding protein (AGP/EBP), C-reactive protein 2 (CRP2) とそれぞれの研究者が独自に 名づけていた。ささに複雑なことに $\mathrm{C} / \mathrm{EBP} \beta$ は翻 訳時の調節により， $\mathrm{N}$ 末端領域の転写活性化ドメ インを欠いた転写抑制因子としても働く, その場合 は, liver inhibitory protein (LIP), silencer factor B （SF-B）と呼ばれていた. 当研究室の文献紹介セミ ナーで, 同一遺伝子であることに気付かず異なる遺 
伝子として紹介したため指摘したこともあつたが, 若い学生たちが古い文献に目を通すときは是非遺伝 子の名前には注意を払ってほしいと思う。

余談を飛び越して完全に脱線したが，TCL/ TC10 $\beta \mathrm{L}$ と fad158についてはこれらのホモノック アウトマウスからは興味ある知見は残念ながらほと んど得られていない。一方，作製が難航した fad 24 及び fad104 は全く想定外の表現型が観察された。 その詳細については次項の中で記す。

\section{5. fad 24 の有する多彩な生理機能}

\section{5-1. 肥満形成における fad 24 の機能 ノック} アウトマウスと異なり，トランスジェニックマウス は比較的短い日数で作製できることから，fad 24 過 剩発現トランスジェニックマウスを作製した。 mouse embryonic fibroblast（MEF，マウス胎仔由来 線維芽細胞）を用いて脂肪細胞分化を検討すると, $\mathrm{fad} 24$ 過剩発現により脂肪細胞分化が促進された.

また，普通食を与えた 23 週齢の fad 24 過剩発現マ ウスにおいて, 脂肪細胞数の増加, 小型成熟脂肪細 胞の割合の増加, 血清中のアディポネクチンの増加 が観察された。ささらに、インスリン感受性の増加も 観察された。一方， 3 週齢より高脂肪食を与えた 15 週齢マウスで検討すると，普通食の場合と同様に脂 肪細胞数の増加, 小型成熟脂肪細胞の割合の増加が 観察されたものの，アディポネクチンの増加はわず かであり，インスリン感受性については明確な結果 は得られなかった．高脂肪食での効果が小さいこと から今後の検討が必要なものの，これらの結果は，

fad 24 が in vivo においても脂肪細胞分化制御因子 として働くとともに, 脂肪細胞数及び細胞の大きさ にも係わっていることを示している. ${ }^{41)}$

5-2. MCE における fad 24 の機能 前述のよ うに多くの因子が MCE に係わっているが，fad 24 も MCE を正に制御していることが明らかとなった。

FAD24 は，酵母 Noc3p と類似したアミノ酸配列を 有しており, Noc3p が複数の DNA 複製因子と相互 作用することにより DNA 複製開始を制御している ことが報告された. ${ }^{42)}$ そこで，FAD24 が哺乳動物 の系でも DNA 複製因子と相互作用するか否か検討 したところ, histone acetyltransferase binding to ORC1（HBO1）と相互作用することが明らかになつ た. ${ }^{43)}$ 興味あることに, HBO1 も fad24 と同様に脂 肪細胞分化過程における MCE を正に制御している
ことを明らかにした。 が HBO1 との相互作用を介して MCE 及び脂肪細 胞分化を制御していることを示唆している。 そこで 次に細胞分裂期における FAD24 と HBO1 の局在を 調べたところ，分裂終期に共局在することが明らか となった。ささらにクマチン免疫沈降法により FAD24 及び HBO1 の複製起点への局在を検討した 結果，FAD24 は HBO1 を複製起点へとリクルート することにより DNA 複製を正に制御しその結果 MCE が進行することが明らかとなった. ${ }^{43)}$

\section{5-3. 通常の細胞増殖における fad24 の機能}

上記のように脂肪細胞分化初期の MCE において, fad24 が DNA 複製制御に関与することが明らかに なったが，この機能が脂肪細胞分化に特異的か否か 次に検討した。 その結果, fad 24 は脂肪細胞分化の みならず，通常の細胞増殖においても DNA 複製を 正に制御することが明らかになった. ${ }^{44)}$

5-4. 細胞がん化における $\mathrm{fad} 24$ の機能

DNA 複製制御の異常は細胞がん化を引き起こす ことが知られている。 そこで，細胞がん化の 1 つの 指標である足場非依存性増殖能を測定するソフトア ガロースアッセイにより, 細胞がん化における fad 24 の機能を解析した。 その結果, fad 24 過剩発 現はがん遺伝子 rasによるトランスフォーム能を抑 制することが明らかとなつた。ささらに，その抑制機 構として，fad 24 が転写因子 nuclear factor- $\kappa \mathrm{B}$ (NF$\kappa \mathrm{B})$ の活性を阻害することも明らかにした. ${ }^{45)}$

このように, fad 24 は正常細胞, 脂肪細胞分化に おける MCE，細胞がん化など様々な場面において DNA 複製を介して細胞の増殖・分化に深く係わつ ていることが明らかとなった。

5-5. 初期胚発生における $\mathrm{fad} 24$ の機能 前述 したように, fad 24 は単離当時データベースに登録 のない未知遺伝子であったため，並行して全身性 ノックアウトマウスを作製した，その表現型は，上 記 5-2. と5-3.の結果を反映したものとなつた。す なわち，fad 24 が細胞増殖に大きく寄与しているこ とを反映し, $\mathrm{fad} 24$ ホモ欠損マウスは胎生致死であ り, 胎生 9.5 日齢においても全く存在しないことが 明らかとなった。そこで次に，体外受精で得た受精 卵を in vitroで培養し 2-4 日にかけて詳細に検討し たところ，胚盤胞形成過程で fad 24 が重要な役割を 果たしていることが明らかとなった（Fig. 3).46）さ 


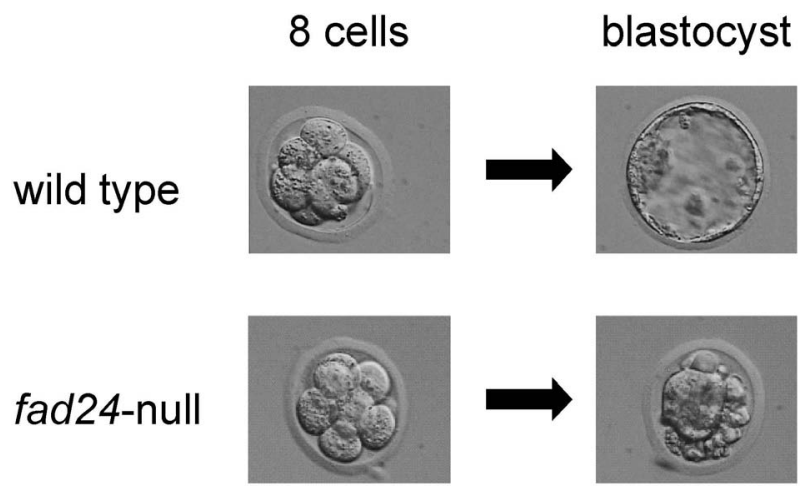

Fig. 3. Disruption of fad24 Results in Early Embryonic Lethality ${ }^{46)}$

Pre-implantation development of fad 24 deficient embryos from the 8cell to the blastocyst stage. fad24-null mutants failed to develop into blastocysts.

らに詳細に検討すると, 胚盤胞の 1 つ前のステージ である桑実胚において, 細胞の数が少ない, すなわ ち増殖が不十分であることも明らかとなった．桑実 胚形成前のステージである 8 細胞までは，母親由来 の遺伝子産物 FAD24 が機能している可能性もあ る。したがって，受精卵から 8 細胞に至る過程にお ける fad 24 の機能については更なる解析が必要であ るものの，新規遺伝子 $f a d 24$ は脂肪細胞分化のみな らず，生命機能維持の基礎を担う重要な制御因子で あることを明らかにした。

\section{6. fad104 の有する多彩な生理機能}

6-1. 肺形成における fad104 の機能 fad104 についてもノックアウトマウスを作製した. ${ }^{47)}$ その 結果，木モ欠損マウスは，出生はするものの出生 1 日以内に死亡することがわかった。 そこで 18.5 日 目の胎仔を観察したところ, 摘出後の呼吸の頻度が 低く, 30 分以内にチアノーゼを起こすことが明ら かとなつた. ${ }^{48)}$ また肺が小さく無気肺の症状を呈す ることもわかった。そこで肺形成時における fad104 の機能を解析したところ, 肺胞上皮 II 型細 胞の分化・成熟に重要な役割を果たしており, fad104 ホモ欠損マウスは肺胞上皮 II 型細胞の未成 熟に伴う呼吸不全により死亡することを明らかにし た. ${ }^{48)}$

6-2. 骨形成における fad104 の機能 上記の fad104 ホモ欠損マウスから MEF を調製し脂肪細胞 への分化を検討したところ，予想通りその分化は抑 制された。次にこの MEF をヌードマウス皮下に移 植し，3 週間後の移植片を摘出し観察した。その結 wild type fad104-null
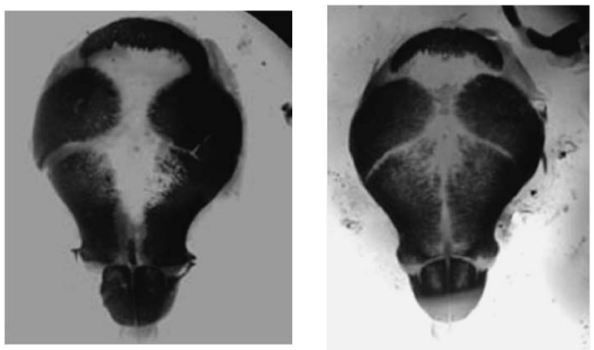

anterior fontanel
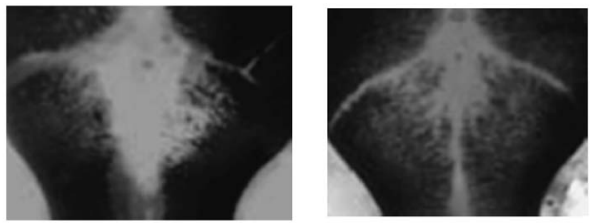

Fig. 4. Disruption of fad104 Causes Skeletal Deformities in the Anterior Fontanel ${ }^{50}$ )

A superior view of the stained calvaria in wild-type and fad104-deficient mice at E18.5.

果, 野生型 MEF では脂肪細胞への分化と中性脂肪 の蓄積が観察されたのに対して，fad104 ホモ欠損 マウス MEFでは脂肪細胞は見い出されなかっ た. ${ }^{49)} こ の$ 結果は, in vivoにおいてもfad104 が脂 肪細胞分化に深く係わっていることを示している. 興味あることに, fad104 ホモ欠損マウス MEF 由来 の移植片では脂肪細胞の代わりに骨様細胞が観察さ れたことより，fad104が骨分化に負に係わってい ることが強く示唆された.

そこで次に fad104 欠損が MEF の骨形成に与え る影響について検討した。 その結果, fad104 欠損 により骨分化が促進することが明らかとなつた。ま たこのとき，骨細胞への運命を決定し，骨分化のマ スターレギュレーターと言われている runt related transcription factor 2 (runx2)の発現を検討すると, fad104 欠損により上昇することも明らかとなっ た. ${ }^{49)}$

以上の結果は, fad104 欠損により骨分化が促進 することを示している，そこで 18.5 日目の fad104 ホモ欠損胎仔を注意深く観察すると，野生型と比較 して頭部が高く盛り上がっているように見えた，次 に頭部骨格標本を作製比較したところ，fad104 ホ モ欠損マウスの頭蓋は, 野生型と比較して後頭部か ら鼻先までが短く横幅も短いことが明らかになつ た.さらに,fad104 ホモ欠損マウスの大泉門は骨 化が進夕過ぎており，早期に閉鎖されていることも 
injected with control cells

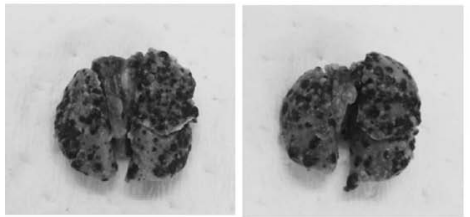

injected with FAD104

over-expressing cells

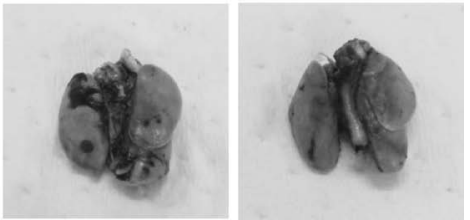

Fig. 5. Over-expression of FAD104 Suppresses Metastasis of B16F10 Cells ${ }^{51)}$

Appearance of murine lungs $15 \mathrm{~d}$ after injection of FAD104 over-expressing cells and control cells through the tail vein of 6-week-old mice.

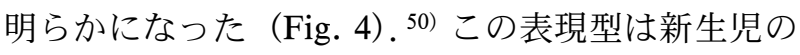
頭蓋縫合早期癒合症（Craniosynostosis）によく似 ていることから，今後の詳細な解析が待たれる.

次に初代培養 calvaria（頭蓋冠）細胞を用いて骨 分化過程における fad104の関与について検討し た。その結果, fad104 欠損により calvaria 細胞の 骨分化能は元進した。さらにそのとき, bone morphogenetic protein/SMAD (BMP/SMAD) シグナ ルも fad104 欠損により増強されることが明らかと なった。以上の結果より, fad104 は BMP/SMAD シグナルを介して骨分化を負に制御していることが 明らかとなった. ${ }^{50)}$

6-3. 正常細胞の増殖, 接着, 伸展, 移動に与え る fad104 の影響 fad104 ホモ欠損マウスから MEF を調製し, 細胞の増殖能, 接着能, 伸展能, 移動能について野生型 MEF と比較したところ, fad104 欠損はいずれにおいても抑制的に働いた. また，細胞のストレスファイバー形成も抑制し た. ${ }^{47)}$

6-4. がん細胞の浸潤，転移に fad104 が与える 影響前述の細胞の接着, 移動は, がん細胞の浸 潤，転移にも深く関係している。そこで次にがん細 胞を用いてその浸潤，転移能に及ぼすfad104 の影 響について検討した。まずはじめにヒトメラノーマ 由来の高転移性及び低転移性細胞における fad104 の発現量を検討したところ，高転移性細胞の方が fad104の発現量が低いことがわかった。そこで, 低転移性細胞にはfad104 抑制系を, 高転移性細胞 には fad104 過剩発現系を導入したところ, いずれ の場合もがん細胞の浸潤を fad104 が抑制すること を見い出した. ${ }^{51)}$ 次に, fad104 過剩発現メラノーマ 細胞をマウス尾静脈に投与し, 肺へのがん細胞の転 移能を検討したところ, fad104 過剩発現により肺
への転移が抑制された（Fig. 5)。また， signal transducer and activator of transcription 3 (STAT3) にfad104 が結合しリン酸化を阻害することにより STAT3 シグナルを抑制することも見い出した.こ れらの結果より, fad104 が STAT3 シグナルを介し てがん細胞の浸潤及び転移を抑制することが明らか となった. ${ }^{51)}$

\section{7. おわりに}

当研究室における 18 年間の研究成果を中心に概 説した。 途中で大きく展開し，脂肪細胞分化だけで なく, 骨形成, 肺形成, 胚形成及び細胞がん化の方 向にも進んだ。しかし，この展開は予期していな かったわけではない. 脂肪細胞分化初期の分子機構 解明を新たなテーマとして始めたのは，C/EBP ファミリーの存在が大きい. その頃当研究室では, 腫瘍マーカー遺伝子の発現制御機構解明に力を入れ ており，C/EBP ファミリーが遺伝子発現を負に制 御するサイレンサーとして機能することを明らかに したところであった. ${ }^{52)} も と も と \mathrm{C} / \mathrm{EBP} \alpha$ は肝臓 におけるアルブミンの発現に, $\mathrm{C} / \mathrm{EBP} \beta$ とC/ $\operatorname{EBP} \delta$ は炎症に関与する転写因子として同定され た. ${ }^{40)}$ 一方, 前述のように $\mathrm{C} / \mathrm{EBP}$ ファミリーは脂 肪細胞分化に深く係わっていた. ${ }^{8-11)}$ また，アメフ ラシを用いた研究で記憶に係わるとの報告がなされ

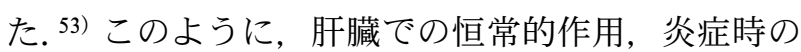
特異的作用, 脂肪細胞分化, 記憶そしてサイレン サ一作用というように一見関係のない事象が特定の 転写因子によって制御されていることに驚くととも にその作用機構についていろいろと議論したことを 今でもよく覚えている. そこで, 脂肪細胞分化初期 に働く遺伝子を新たに見い出すことができれば，そ れらは多彩な機能を有しているはずであると予想し て研究を開始した。 
その頃は，少なくとも 10 万種類の遺伝子をヒト は持っているだろうと言われていた時代であった が，ヒトゲノム解析の進展とともに，ヒトの有する 遺伝子の数は 10 万種類よりもはるかに少ないと推 定されるようになった。実際，2001 年のゲノム概 略版発表の際には 34000 程度となり，2004 年の詳 細版では約 22000 となった。並行して，転写後調 節，翻訳前後の調節機構に関して新たな知見が次々 と見い出されるとともに，マイクロ RNAなど non-coding RNA (ncRNA) の登場により, 遺伝子 発現のセントラルドグマが大きく塗り替えられたの はご承知の通りである．現在は，いろいろな分野で ハイスループット的に一網打尽にする戦略がよく用 いられている。 しかし，結果として個々の遺伝子の 機能解析が遅れている，若しくは見逃されているの も事実である．家内工業的ではあるが，個々の遺伝 子を丹念に解析することも極めて重要であると私自 身は考えている，その意味では，fad24 や fad104 が多彩な生理機能を有していることを部分的にせよ 明らかにできたことは嬉しい限りである，今後様々 なアプローチにより，芸術的とも言えるヒト個体の 生命維持機構が明らかにされ，各種疾患の原因解明 や新たな治療薬の開発に結びつくことを願つている.

謝辞本研究は, 平成 9 年に大阪大学薬学部環 境代謝化学講座（平成 10 年大学院改組により薬学 研究科微生物動態学分野) において, 西原 力教授 のご指導の下新たに立ち上げ今に至ったものです。 この場をお借りして恩師西原先生に篤く御礼申し上 げます。平成 12 年に名古屋市立大学薬学部微生物 薬品学講座（平成 14 年大学院改組により薬学研究 科分子生物薬学分野) に移動後, 研究は大きく進展 しましたが，本研究は両大学の多くの学生さん及び 多くの他研究室の共同研究者の皆様とともに行った ものです．特にプロジェクト立ち上げ 2 年目から現 在まで一緒に研究を行っている名古屋市立大学西塚 誠講師，また私が大学本部における管理運営のた め，研究室を留守にすることが多かった丸 9 年もの 長い間，ご自身のプロジェクトに加えて「肥満グ ループ」の面倒を見て下さった長田茂宏准教授に深 謝するとともに，本研究の推進に真摰に取り組んで 下さった多くの学生・院生の皆様及び多大なご協力 を賜りました共同研究者の皆様に心より感謝申し上
げます。

利益相反＼cjkstart開示すべき利益相反はない.

\section{REFERENCES}

1) Kahn S. E., Hull R. L., Utzschneider K. M., Nature, 444, 840-846 (2006).

2) Rosen E. D., Spiegelman B. M., Nature, 444, 847-853 (2006).

3) Boden G., Curr. Opin. Endocrinol. Diabetes Obes., 18, 139-143 (2011).

4) Wang Z. V., Li D. L., Hill J. A., $J$. Cardiovasc. Pharmacol., 63, 302-313 (2014).

5) Friedman J. M., Nature, 459, 340-342 (2009).

6) Rosen E. D., Spiegelman B. M., Cell, 156, 2044 (2014).

7) Frood S., Johnston L. M., Matteson C. L., Finegood D. T., Curr. Obes. Rep., 2, 320-326 (2013).

8) Mandrup S., Lane M. D., J. Biol. Chem., 272, 5367-5370 (1997).

9) Rosen E. D., Walkey C. J., Puigserver P., Spiegelman B. M., Genes Dev., 14, 1293-1307 (2000).

10) Farmer S. R., Cell Metab., 4, 263-273 (2006).

11) Rosen E. D., Hsu C. H., Wang X., Sakai S., Freeman M. W., Gonzalez F. J., Spiegelman B. M., Genes Dev., 16, 22-26 (2002) .

12) Sadowski H. B., Wheeler T. T., Young D. A., J. Biol. Chem., 267, 4722-4731 (1992) .

13) Imagawa M., Tsuchiya T., Nishihara T., Biochem. Biophys. Res. Commun., 254, 299305 (1999).

14) Imagawa M., Farumashia, 36, 780-784 (2000) .

15) Nishizuka M., Tsuchiya T., Nishihara T., Imagawa M., Biochem. J., 361, 629-633 (2002) .

16) Nishizuka M., Yakugaku Zasshi, 123, 949-956 (2003).

17) Nishizuka M., Honda K., Tsuchiya T., Nishihara T., Imagawa M., J. Biol. Chem., 276, 29625-29627 (2001).

18) Kitamura A., Nishizuka M., Tominaga K., Tsuchiya T., Nishihara T., Imagawa M., Biochem. Biophys. Res. Commun., 287, 435439 (2001).

19) Nishizuka M., Arimoto E., Tsuchiya T., Nishihara T., Imagawa M., J. Biol. Chem., 
278, 15279-15284 (2003).

20) Hishida T., Naito K., Osada S., Nishizuka M., Imagawa M., FEBS Lett., 581, 4272-4278 (2007).

21) Hishida T., Naito K., Osada S., Nishizuka M., Imagawa M., Biochem. Biophys. Res. Commun., 370, 289-294 (2008) .

22) Tominaga K., Kondo C., Kagata T., Hishida T., Nishizuka M., Imagawa M., J. Biol. Chem., 279, 34840-34848 (2004).

23) Tominaga K., Kondo C., Johmura Y., Nishizuka M., Imagawa M., FEBS Lett., 577, 49-54 (2004) .

24) Tominaga K., Johmura Y., Nishizuka M., Imagawa M., J. Cell Sci., 117, 6217-6226 (2004) .

25) Tominaga K., Kagata T., Johmura Y., Hishida T., Nishizuka M., Imagawa M., FEBS J., 272, 1590-1599 (2005).

26) Hishida T., Eguchi T., Osada S., Nishizuka M., Imagawa M., FEBS J., 275, 5576-5588 (2008) .

27) Taylor K. M., Nicholson R. I., Biochim. Biophys. Acta, 1611, 16-30 (2003).

28) Taylor K. M., Morgan H. E., Johnson A., Nicholson R. I., FEBS Lett., 579, 427-432 (2005) .

29) Eide D. J., Biochim. Biophys. Acta, 1763, 711-722 (2006).

30) Tang Q. Q., Otto T. C., Lane M. D., Proc. Natl. Acad. Sci. USA, 100, 44-49 (2003).

31) Tang Q. Q., Otto T. C., Lane M. D., Proc. Natl. Acad. Sci. USA, 100, 850-855 (2003).

32) Guo L., Li X., Tang Q. Q., J. Biol. Chem., 290, 755-761 (2015).

33) Hishida T., Nishizuka M., Osada S., Imagawa M., Biochimie, 91, 654-657 (2009) .

34) Kawaji A., Nishizuka M., Osada S., Imagawa M., Biol. Pharm. Bull., 33, 404-409 (2010) .

35) Kawaji A., Ohnaka Y., Osada S., Nishizuka M., Imagawa M., Biol. Pharm. Bull., 33, 773779 (2010).

36) Nishizuka M., Hayashi T., Asano M., Osada S., Imagawa M., Int. J. Mol. Sci., 15, 2274322756 (2014).

37) Hayashi T., Nozaki Y., Nishizuka M., Ikawa M., Osada S., Imagawa M., Biol. Pharm.
Bull., 34, 1257-1263 (2011).

38) Abascal F., Zardoya R., Bioessays, 34, 551560 (2012).

39) Visvikis O., Maddugoda M. P., Lemichez E., Biol. Cell, 102, 377-389 (2010).

40) Imagawa M., Seikagaku, 65, 120-125 (1993).

41) Johmura Y., Watanabe K., Kishimoto K., Ueda T., Shimada S., Osada S., Nishizuka M., Imagawa M., Biol. Pharm. Bull., 32, 1656-1664 (2009).

42) Zhang Y., Yu Z., Fu X., Liang C., Cell, 109, 849-860 (2002).

43) Johmura Y., Osada S., Nishizuka M., Imagawa M., J. Biol. Chem., 283, 2265-2274 (2008).

44) Johmura Y., Osada S., Nishizuka M., Imagawa M., Biol. Pharm. Bull., 31, 1092-1095 (2008).

45) Johmura Y., Suzuki M., Osada S., Nishizuka M., Imagawa M., Biochem. Biophys. Res. Commun., 369, 464-470 (2008).

46) Ochiai N., Nishizuka M., Miyamoto T., Miyoshi I., Ikawa M., Osada S., Imagawa M., Biochem. Biophys. Res. Commun., 438, 301305 (2013).

47) Nishizuka M., Kishimoto K., Kato A., Ikawa M., Okabe M., Sato R., Niida H., Nakanishi M., Osada S., Imagawa M., Exp. Cell Res., 315, 809-819 (2009) .

48) Kishimoto K., Nishizuka M., Ueda T., Kajita K., Ugawa S., Shimada S., Osada S., Imagawa M., Exp. Cell Res., 317, 2110-2123 (2011).

49) Kishimoto K., Kato A., Osada S., Nishizuka M., Imagawa M., Biochem. Biophys. Res. Commun., 397, 187-191 (2010).

50) Kishimoto K., Nishizuka M., Katoh D., Kato A., Osada S., Imagawa M., J. Biol. Chem., 288, 31772-31783 (2013).

51) Katoh D., Nishizuka M., Osada S., Imagawa M., Plos One, 10, e0117197 (2015).

52) Osada S., Takano K., Nishihara T., Suzuki T., Muramatsu M., Imagawa M., J. Biol. Chem., 270, 31288-31293 (1995).

53) Alberini C. M., Ghirardi M., Metz R., Kandel E. R., Cell, 76, 1099-1114 (1994). 